\title{
Kajian Pola Aliran Air Tanah Di Area Kampus Utama Universitas Muhammadiyah Purwokerto
}

\author{
A Study of Groundwater Flow Pattern in Area of Main Campus of \\ Universitas Muhammadiyah Purwokerto
}

\author{
Wiwin Bregasnia ${ }^{1}$, Suwarsito $^{2}$, Esti Sarjanti ${ }^{2}$ \\ ${ }^{1,2}$ Pendidikan Geografi, Universitas Muhammadiyah Purwokerto \\ ${ }^{1}$ wiwin.bregasnia@gmail.com
}

\begin{abstract}
ABSTRAK
Airtanah merupakan air yang menempati pori-pori batuan di bawah permukaan tanah pada zona jenuh air. Air tanah saat ini mempunyai peranan yang sangat penting bagi kehidupan manusia. Tujuan penelitian adalah untuk mengetahui pola aliran air tanah di area kampus utama Universitas Muhammadiyah Purwokerto (UMP). Penelitian ini menggunakan metode survei lapangan. Survei lapangan dilakukan dengan mensensus sumur di area kampus utama UMP untuk memperoleh data kedalaman airtanah. Populasi penelitian adalah air tanah di area kampus utama UMP yang berlokasi di Desa Dukuhwaluh, Kecamatan Kembaran, Kabupaten Banyumas. Teknik pengambilan sampel menggunakan purposive sampling. Sampel penelitian sebanyak 16 titik sumur yang ada di kampus utama UMP. Pengumpulan data air tanah dilakukan dengan mengukur kedalaman dan koordinat sumur-sumur di kampus utama UMP menggunakan meteran dan GPS (Global Positioning System). Pengolahan data penelitian dilakukan menggunakan Sofware Surfer 13 untuk mendapatkan hasil peta pola aliran air tanah. Analisis data dilakukan secara deskriptif kualitatif untuk mendeskripsikan pola aliran air tanah di area kampus utama UMP. Hasil penelitian menunjukkan bahwa bahwa pola aliran air tanah di area kampus utama UMP menunjukkan pergerakan dari arah barat laut menuju ke arah tenggara. Pola aliran airtanah cenderung mengikuti kontur permukaan tanah.
\end{abstract}

Kata-kata kunci: Pola aliran, Air tanah, Kampus Utama Universitas Muhammadiyah Purwokerto

\begin{abstract}
Ground water was water located in the rock pores layer under soil surface. Groundwater currently has a very important role for human life. The aim of study was to determine the groundwater flow pattern in area of main campus of Universitas Muhammadiyah Purwokerto (UMP). The study used a field survey method. Field surveys were carried out by census wells in area of main campus of UMP to obtain groundwater depth data. The research population were groundwater in area of main campus of UMP that located in Dukuhwaluh Village, Kembaran District, Banyumas Regency. The sampling technique used purposive sampling. The research sample consisted of 16 wells on area of main campus of UMP. Groundwater data was collected by measuring the depth and coordinates of the wells using Global Positioning System. Data were processed using Surfer 13 software to obtain groundwater flow pattern maps. Data were analyzed by descriptive qualitative to describe the groundwater flow pattern in area of main campus of UMP. The results revealed that groundwater flow
\end{abstract}


patterns moved towards the northwest to the southeast. Groundwater flow patterns tend to follow the contours of soil surface.

Keywords: flow patterns, groundwater, main campus of Universitas Muhammadiyah Purwokerto

\section{PENDAHULUAN}

Airtanah merupakan air yang menempati pori-pori batuan di bawah permukaan tanah pada zona jenuh air (Santosa dan Adji, 2014). Menurut Sutandi (2012), air tanah pada umumnya terdapat dalam lapisan tanah baik yang dekat dengan permukaan tanah sampai dengan yang jauh dari permukaan tanah. Air tanah yang terdapat di bawah permukaan berinteraksi dengan lapisan tanah berupa pasir sebagai tempat keterdapatan (aquifer) air tanah (Guskarnali et al., 2015).

Sumberdaya airtanah bersifat dapat diperbaharui secara alami karena airtanah merupakan bagian yang tidak terpisahkan dalam siklus hidrologi (Asrifah, 2012). Keberadaan airtanah dapat dijumpai di hampir seluruh tempat di bumi, bahkan di bawah lapisan es yang membeku airtanah dapat ditemukan (Asdak, 1995). Keterdapatan airtanah bergantung pada ada tidaknya lapisan batuan yang dapat menyimpan airtanah. Airtanah berada dalam formasi geologi yang disebut sebagai akuifer. Akuifer merupakan formasi yang dapat menyimpan dan mengalirkan air dalam jumlah yang cukup, yang artinya mampu mengaliri suatu sumur, sungai dan mataair (Sudarmadji et $a l ., 2016)$. Besarnya airtanah yang dapat disimpan dalam akuifer bergantung dari sifatsifat akuifer tersebut serta luas cakupan dan frekuensi imbuhan (Linsley and Franzini, 1985).

Air tanah saat ini sudah mempunyai peranan yang sangat penting bagi kehidupan manusia. Air tanah telah menjadi sumber air utama untuk memenuhi kebutuhan pokok hajat hidup orang banyak, seperti untuk air minum, rumah tangga, industri, irigasi, pertambangan, perkotaan dan lainnya. Air tanah sekarang ini sudah menjadi komoditas ekonomis bahkan di beberapa wilayah sudah menjadi komoditas strategis. Diperkirakan, 70\% kebutuhan air bersih untuk penduduk dan 90\% kebutuhan air untuk kepentingan industri dipenuhi dari air tanah.

Kawasan kampus utama Universitas Muhammadiyah Purwokerto (UMP) yang terletak di Desa Dukuhwaluh, Kecamatan Kembaran, Kabupaten Banyumas terletak di dataran aluvial kaki Gunung Slamet membujur dari arah utara ke tenggara dan berada di sisi timur dari wilayah Kabupaten Banyumas (Sarjanti dan Sriwanto, 2015). Dataran kaki Gunung Slamet adalah satuan bentuklahan yang lebih datar dan terbentuk dari pengendapan material oleh proses fluvial, sedimentasi mulai aktif, kemiringan lereng dari agak landai sampai landai, dan material permukaan didominasi oleh kerikil dan pasir kasar. Secara lateral, sebaran batuan ini akan mengkontrol pola aliran air tanah di daerah tersebut (Hadian et al., 2015).

Luas lahan kampus utama UMP seluas 10,3 ha, yang digunakan untuk gedung perkuliahan, perkantoran, dan laboratorium. Dengan adanya keberadan kampus utama UMP, dampak yang terjadi adalah penurunan muka air tanah yang berada di kampus UMP dan sekitarnya. Penurunan ini diduga karena adanya ketidakseimbangan antara imbuhan air tanah (input) dengan pengambilan air tanah (output). Pada saat musim kemarau sekarang ini, beberapa titik sumber air di area kampus utama UMP mengalami kekeringan, padahal sudah beberapa kali dilakukan upaya memperdalam sumber air beberapa meter. Sedangkan pada musim hujan, beberapa tempat di kawasan kampus utama UMP sering terjadi luapan atau banjir yang disebabkan oleh kurangnya daerah resapan air hujan. 
Berbagai tindakan telah dilakukan oleh UMP untuk mempertahankan keberadaan air tanah di area kampus, seperti pembuatan kolam penampungan dan sumur resapan. Namun kenyataannya, pada saat musim hujan masih sering terjadi banjir di area kampus utama UMP dan sekitarnya, sedangkan pada saat musim kemarau kekurangan air tanah. Tujuan penelitian ini adalah untuk mengetahui pola aliran air tanah di area kampus utama Universitas Muhammadiyah Purwokerto.

\section{METODE}

Penelitian ini menggunakan metode survei lapangan. Survei lapangan dilakukan dengan mensensus sumur di area kampus utama UMP untuk memperoleh data kedalaman airtanah. Populasi penelitian adalah air tanah di area kampus utama UMP yang berlokasi di Desa Dukuhwaluh, Kecamatan Kembaran, Kabupaten Banyumas. Teknik pengambilan sampel menggunakan purposive sampling. Sampel penelitian sebanyak 16 titik sumur yang ada di area kampus utama UMP. Pengumpulan data air tanah dilakukan dengan mengukur kedalaman dan koordinat sumur-sumur di area kampus utama UMP menggunakan meteran dan GPS (Global Positioning System). Pengolahan data penelitian dilakukan menggunakan Sofware Surfer 13 untuk mendapatkan hasil peta pola aliran air tanah. Analisis data dilakukan secara deskriptif kualitatif untuk mendeskripsikan pola aliran air tanah di area kampus utama UMP.

\section{HASIL DAN PEMBAHASAN}

Kondisi geologi area kampus utama UMP berada pada dua satuan litologi yaitu endapan alluvium (Qa) dan Endapan Lahar Gunung Slamet (Q1s). Endapan lahar Gunung Api Slamet berupa bongkahan batuan vulkanik bersusun andesit-basalt dan alluvium berupa kerikil, pasir dan lempung sebagai hasil endapan sungai (Raharjo et al., 2014). Batuan andesit-basalt berperan sebagai batuan dasar (basement) (Rheswara dan Sehah, 2017).

Berdasarkan Gambar 1 menunjukkan bahwa sebagian besar lahan di Kampus utama UMP (52\%) merupakan bangunan fisik dan jalan. Sisa lahan lainnya merupakan taman, badan air, tanah kosong dan lapangan olah raga. Area resapan yang terdapat di area Kampus utama UMP hanya tersisa 18\%. Karena area resapan yang hanya sedikit tersebut menyebabkan area ini mengalami kekurangan air pada saat musim kemarau, dan mengalami banjir pada saat musim hujan. Jika hal ini tidak diantisipasi, dapat mengakibatkan kekeringan air tanah pada sumur-sumur akan terjadi karena berkurangnya proses infiltrasi air tanah oleh air hujan (recharge area) ke dalam akuifer dan meningkatnya run off (aliran permukaan) di area kampus utama UMP.

Pola aliran airtanah dibuat menggunakan Software Surfer 13 dengan data masukan berupa koordinat dan elevasi titik pengukuran. Secara umum, ketinggian lokasi penelitian dibagi menjadi 3 yaitu dataran rendah $<400$ mdpl, dataran medium $400-700$ mdpl, dan dataran tinggi $>700 \mathrm{mdpl}$ (Istiawan et al., 2019). Elevasi di area kampus utama UMP berdasarkan Google Earth, ketinggian tertinggi sekitar 94,5 mdpl, sedangkan ketinggian terrendah sekitar 88,5 mdpl. Area kampus utama UMP termasuk kedalam dataran rendah. Gambar 2 merupakan gambar elevasi di area kampus utama UMP.

Gambar 2 merupakan kontur kampus utama UMP dalam bentuk 2 dimensi. Interval kontur dalam peta di atas $0,5 \mathrm{~m}$. Titik tertinggi dapat dilihat dalam peta yaitu berwarna merah, sedangkn titik terendah berwarna biru. Posisi titik tertinggi berada di sisi barat dan timur UMP sekitar FKIP dan FEB. Sedangkan titik terrendah berada di sebelah selatan dan sebelah timur UMP sekitar Pascasarjana dan Fakultas Sastra. 


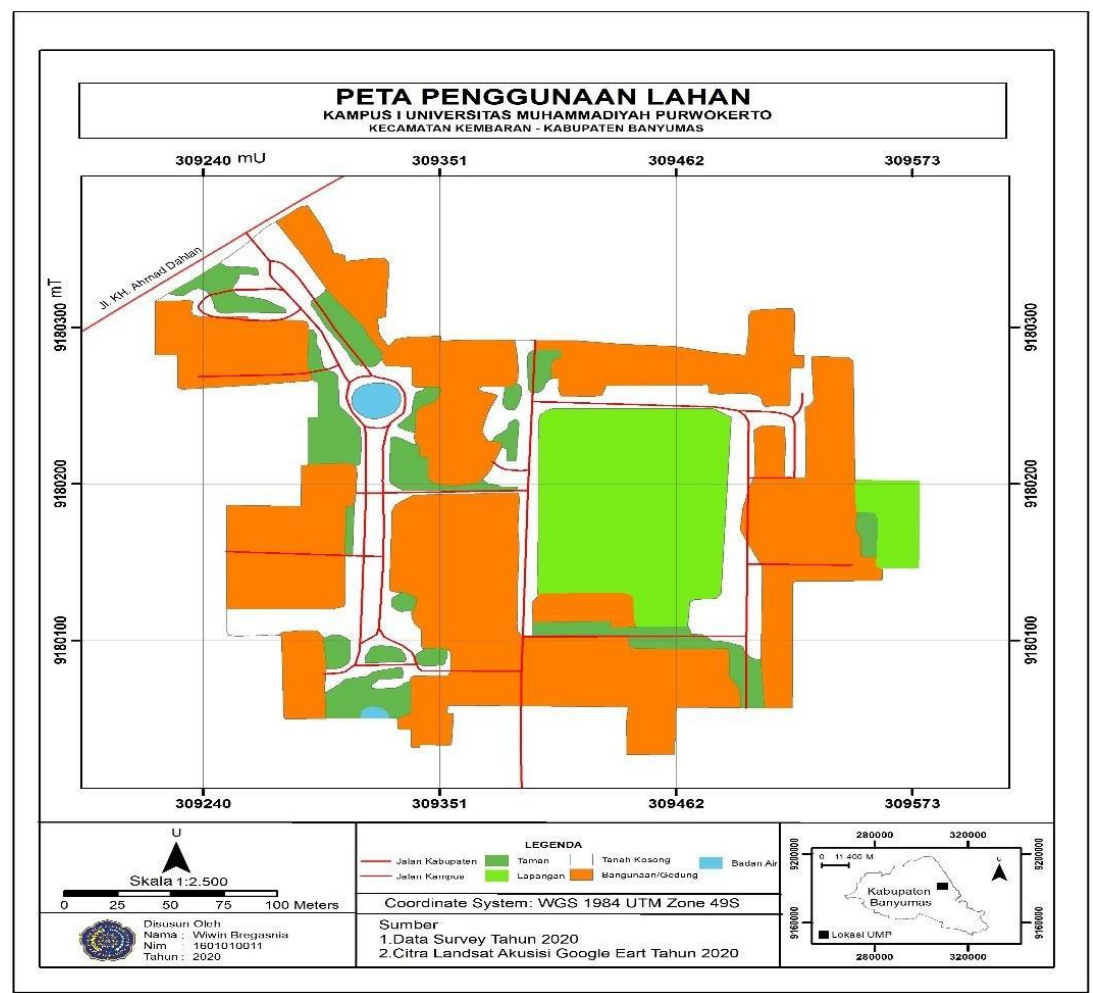

Gambar 1. Peta Penggunaan Lahan di Kampus utama UMP

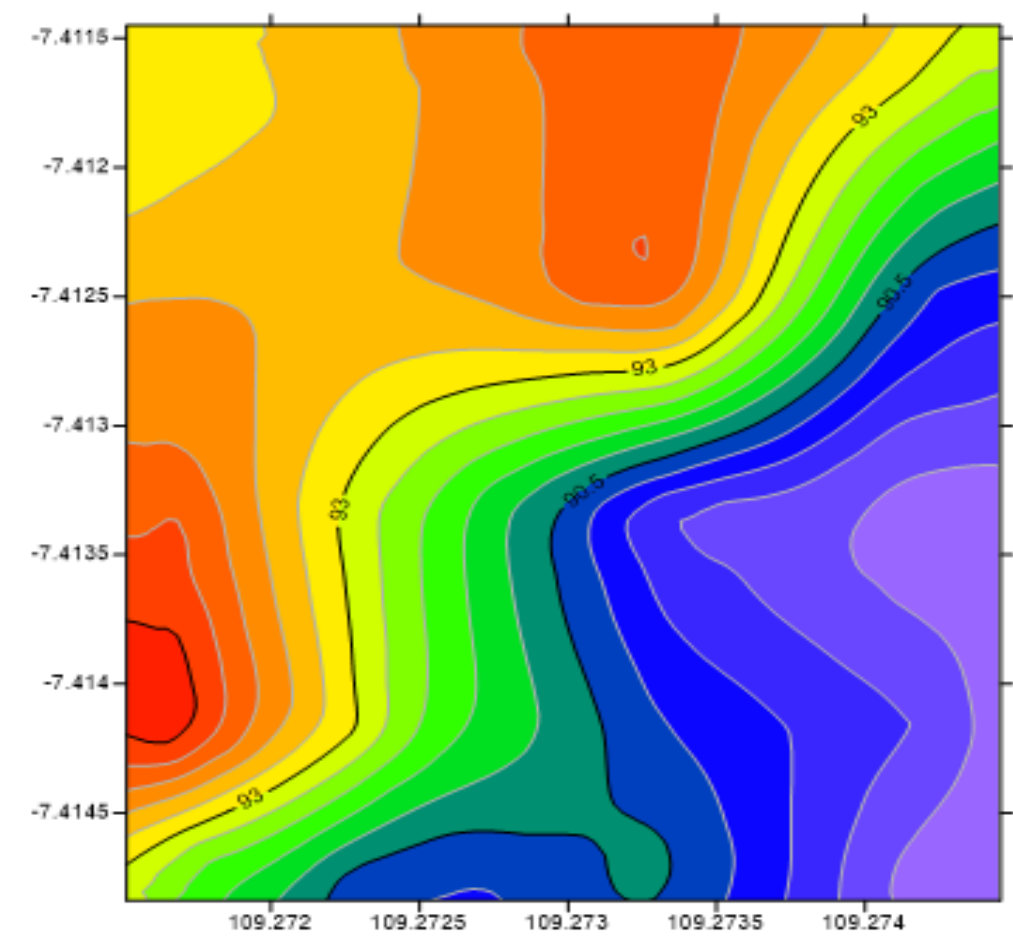

Gambar 2. Kondisi Elevasi Kawasan Kampus utama UMP 
Hasil pengambilan data di lapangan diperoleh data kedalaman sumur-sumur di area kampus utama UMP. Selanjutnya data diolah menggunakan perangkat komputer untuk mendapatkan hasil peta pola aliran air tanah di area kampus utama UMP. Peta kontur air tanah adalah peta yang menghubungkan tempat-tempat yang mempunyai ketinggian muka air tanah yang sama (ketinggian dari permukaan air laut), sedangkan peta pola aliran air tanah adalah peta yang menunjukkan arah aliran air tanah. Pembuatan arah aliran air tanah dilakukan dengan menarik garis arah yang tegak lurus $\left(90^{\circ}\right)$ dengan kontur air tanahnya. Pembuatan peta kontur air tanah menggunakan data ketinggian kontur tanah dari peta topografi digital dari Google Earth.

Pembuatan peta kontur air tanah dilakukan menggunakan Software Surfer 13. Dari peta kontur air tanah yang dibuat, selanjutnya dibuat pola aliran air tanah di area kampus utama UMP. Dari hasil pengamatan di lapangan menunjukkan bahwa kedalaman muka air tanah di area kampus utama UMP berkisar antara 68 - 83 meter. Angka ini menunjukkan kedalaman air tanah dalam. Berdasarkan data kedalaman air tanah tersebut, semua air yang terkandung di area kampus utama UMP terletak pada zona aerasi dan di atas zona saturasi. Air tanah di area kampus utama UMP diperkirakan mempunyai debit yang sedang. Hasil pengolahan data menggunakan aplikasi Software Surfer 13 di area kampus utama UMP diperoleh peta kontur air tanah dan peta pola aliran air tanah yang disajikan pada Gambar 3.

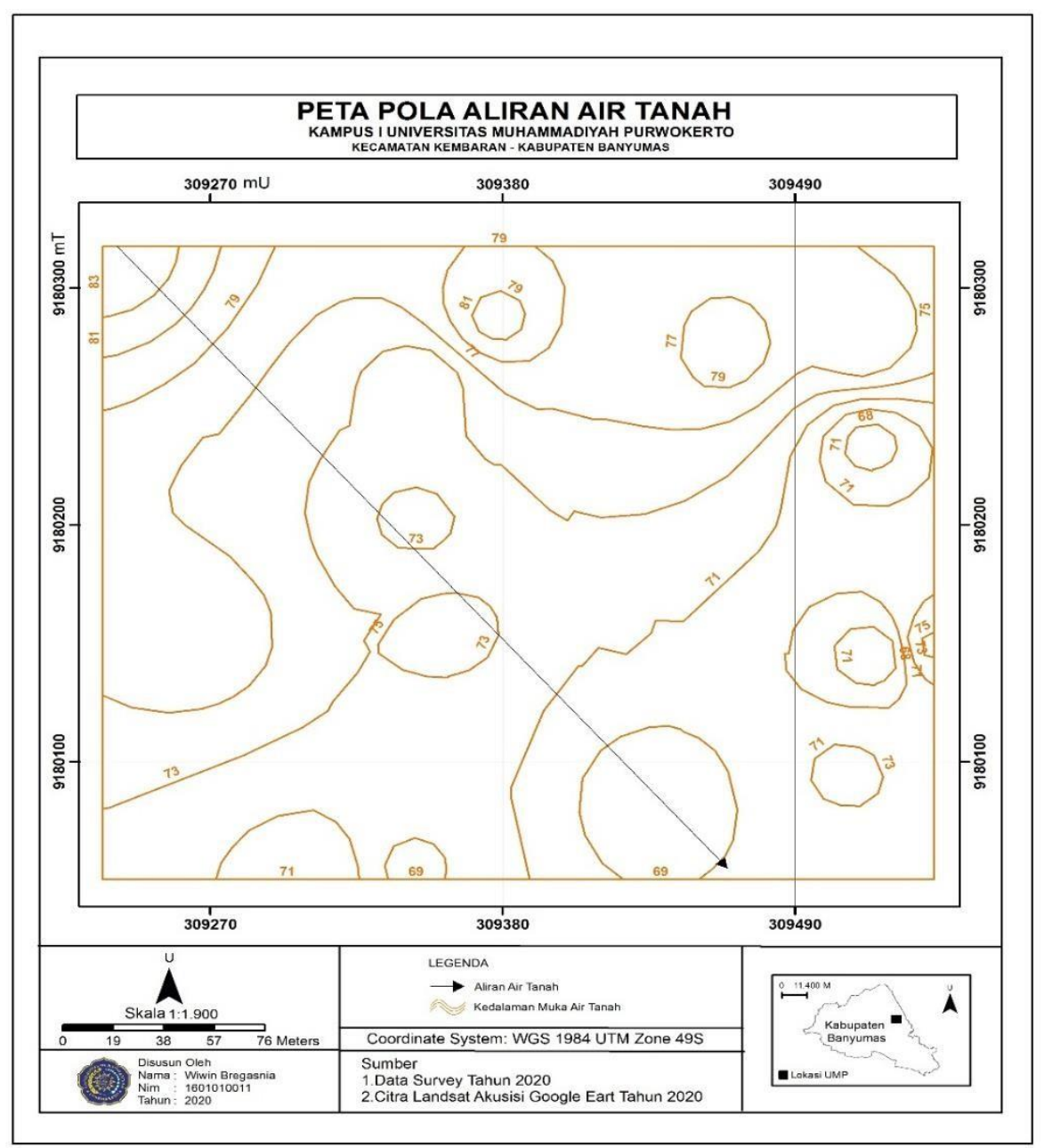

Gambar 3. Peta Pola Aliran Air Tanah di Area Kampus Utama UMP 
Pola aliran air tanah yang dihasilkan dari pembuatan peta kontur aliran air tanah menunjukkan bahwa air tanah bergerak mengarah dari arah barat laut menuju ke tenggara. Pola aliran airtanah cenderung mengikuti kontur permukaan tanah seperti terlihat pada Gambar 2. Dilihat dari alirannya, di sebelah barat area kampus utama UMP disebut aliran influen yaitu area yang mengeluarkan air ke dalam air tanah, sedangkan sebelah tenggara merupakan aliran efluen yaitu area yang menerima air dari air tanah yang berupa mata air di dalam akuifer aluvium dan material gunungapi andesit-basalt. Hal ini sejalan dengan pernyataan Saldanela et al. (2015), bahwa arah aliran air tanah selalu tegak lurus $90^{\circ}$ kontur air tanahnya dan mengalir dari kontur tinggi ke rendah. Selanjutnya dikatakan bahwa air tanah mengalir pada suatu penampang yang seragam dengan gaya gravitasi yang diperoleh dari kemiringan kontur air tanah (Hardjito, 2014). Air tanah mengalami pergerakan di dalam akuifer dengan kecepatan tertentu sehingga memiliki potensi air tanah yang bersifat dinamis (Putri et al., 2018). Sistem aliran airtanah pada dasarnya mencakup daerah imbuhan dan daerah lepasan. Kemunculan mataair akibat adanya kontak airtanah dengan batuan impermeable merupakan salah satu penanda daerah lepasan (Kodoatie, 2012).

Pola aliran air tanah di area kampus utama UMP ini berdekatan dengan SubDaerah Aliran Sungai (DAS) Pelus di sebelah barat yang merupakan cabang dari DAS Serayu. Aliran Sub-DAS Pelus berasal dari sumber mata air Gunungapi Slamet. Hal ini dapat dilihat dari hubungan aliran air tanah dengan sungai tersebut yang membawa material aluvium seperti batu pasir, kerikil ke wilayah penelitian.

\section{KESIMPULAN}

Berdasarkan hasil penelitian disimpulkan bahwa pola aliran air tanah di area kampus utama UMP menunjukkan pergerakan dari arah barat laut menuju ke arah tenggara. Pola aliran airtanah cenderung mengikuti kontur permukaan tanah. Untuk pengelolaan luapan atau banjir di lokasi penelitian dapat dilakukan dengan pembuatan sumur resapan seperti embung dan menjaga land cover berupa banyak menanam pohon atau tanaman keras di wilayah penelitian.

\section{DAFTAR PUSTAKA}

Asdak, C., (1995), Hidrologi dan Pengelolaan Daerah Aliran Sungai, Gadjah Mada University Press, Yogayakarta.

Asrifah, D., (2012), Evaluasi Potensi airtanah Bebas untuk Penyediaan Air di Kalasan dan Prambanan, Majalah Geografi Indonesia, 27 (1), 56-78.

Guskarnali. J. Pitulima, dan Mardiah. (2015). Pemetaan Pola Sebaran Air Tanah Menggunakan Metode Geolistrik Untuk Membantu Masyarakat Mencari Aquifer Air Tanah di Desa Jada Bahrain Kecamatan Merawang. Jurnal Pengabdian Kepada Masyarakat Universitas Bangka Belitung Volume 2, Nomor (1): 29-34.

Hadian, M.S.D., N.M. Barkah, B.A. Sistanto, Hendarmawan, dan F. Helmi. (2006). Sebaran akuifer dan pola aliran air tanah di Kecamatan Batuceper dan Kecamatan Benda Kota Tangerang, Propinsi Banten. Jurnal Geologi Indonesia Volume 1 Nomor (3): 115-128.

Hardjito. (2014). Metode Pumping Test Sebagai Kontrol Untuk Pengambilan Airtanah Secara Berlebihan. Jurnal Sains dan Teknologi Lingkungan. Volume 6 Nomor (3): $138-149$.

Istiawan, Nugraha Dewa, dan D. Kastono. 2019. Pengaruh Ketinggian Tempat Tumbuh 
Terhadap Hasil Dan Kualitas Minyak Cengkih (Syzygium Aromaticum (L.) Merr. \& Perry.) Di Kecamatan Samigaluh, Kulon Progo. Yogyakarta. Universitas Gadjah Mada.

Linsley, R. K. and Franzini, J. B. (1985), Teknik Sumberdaya Air Jilid 1 Edisi Ketiga, diterjemahkan oleh Sasongko, D., Erlangga, Jakarta.

Putri, M.A., A.A. Risanti, K.A. Cahyono, L. Latifah dan N. Rahmawati. (2018). Sistem Aliran dan Potensi Airtanah di Sebagian Desa Sembangun Ditinjau dari Aspek Kualitas dan Kuantitas. Majalah Geografi Indonesia Volume 32, Nomor (2): 155 161.

Rheswara, A.P.A. and Sehah. (2017). Pendugaan Lapisan Reservoir Panas Bumi Di Kawasan Gunungapi Slamet Dengan Memanfaatkan Data Anomali Medan Gravitasi Citra Satelit. Jurnal Berkala Fisika Volume 17 Nomor (2): 45-54.

Saldanela, S. Sutikno, dan A. Hendri. (2015). Pemetaan Pola Aliran Air Tanah Berbasis Sistem Informasi Geografis (SIG) di Kawasan Kecamatan Tampan Kota Pekanbaru. Jurnal Online Fakultas Teknik Universitas Riau Volume 2, Nomor (1): 1-6.

Santosa, L.W. dan Adji, T. N., (2014), Karakteristik Akuifer dan Potensi Airtanah Graben Bantul, Gadjah Mada University Press, Yogyakarta

Sarjanti, E., dan S. Sriwanto. (2015). Analisis Tekanan Penduduk Terhadap Lahan Pertanian Di Kecamatan Kembaran Kabupaten Banyumas. Jurnal Geomedia Volume 13 Nomor (1): 71-77.

Sudarmadji, P. Hadi, dan M. Widyastuti, (2016), Pengelolaan Sumberdaya Air Terpadu, Gadjah Mada University Press, Yogyakarta.

Sutandi, M. C. (2012). Air tanah. Bandung : Universitas Kristen Maranatha. 